\title{
From the Editor: Changing of the Guard
}

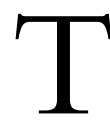

HIS issue marks a changing of the guard at Central European History (CEH). After ten years of exceptional leadership as Editor of CEH, Kenneth 1 Ledford has decided to pass on the baton. Together with Associate Editor Catherine Epstein, who was responsible for the book review section, and his indefatigable assistant Gayle Godek, Ken has made sure that CEH remains the premier journal in the field in North America, reaching the broadest audience of English-speaking scholars working on the history of German-speaking central Europe. These are large shoes to fill, and we all owe them a huge debt of gratitude for a decade of remarkable service to the journal and the profession. The same holds true, of course, for the outgoing members of the Board of Editors.

As Editor, I will work closely with Julia Torrie, the new Associate Editor in charge of book reviews, as well as with the new Board of Editors, a team of highly accomplished scholars from North America and Europe, to ensure that CEH continues not only to publish high-quality scholarship, but also to set the agenda and propose new and innovative directions for the study and historiography of German-speaking Central Europe - as it already has for more than four and a half decades.

To that end, we strongly encourage readers to contact us with any ideas or suggestions for thematic issues, review essays, fora, roundtables, etc. We also warmly invite them to join the Central European History Society. Membership includes an annual subscription to $C E H$, as well as a host of other benefits, including annual awards and funding for scholarly research (http://www.centraleuropean history.org/).

Andrew I. Port

Editor 